\title{
ZBOROVANJE AMERIŠKEGA ZDRUŽENJA GEOGRAFOV 2018
}

\author{
New Orleans, 10.-14. 4. 2018
}

Letno zborovanje Ameriškega združenja geografov (ang. American Association of Geographers oz. AAG) je potekalo med 10. in 14. aprilom 2018 v New Orleansu. Udeležilo se ga je več kot 8.500 udeležencev iz 84 držav (iz Slovenije smo na njem aktivno sodelovali Milan Bufon, Peter Kumer, Mojca Ilc Klun in Boštjan Rogelj). Zborovanje AAG je že pred desetletjem preraslo ameriške okvire. V New Orleansu smo Neameričani predstavljali že skoraj tretjino vseh udeležencev, zaradi česar lahko trdimo, da gre za največje svetovno stanovsko zborovanje geografov. Zborovanje je v zadnjem desetletju postalo tako veliko, da ga lahko gosti le še peščica ameriških velemest.

Velikost dogodka se odraža tudi v tematski pestrosti predstavljenih referatov in posterjev. Udeleženci so predstavili preko 6.000 referatov in posterjev, ki so bili razdeljeni v nekaj več kot 1.600 sekcij. Že bežen pogled na program kaže izjemno vsebinsko, metodološko in teoretsko pestrost predstavljenih raziskav. Na zborovanju so predstavljena praktično vsa področja geografskega raziskovanja, od tistih bolj standardnih do tistih bolj specifičnih. O velikosti dogodka priča podatek, da v najbolj zasedenih terminih sočasno poteka tudi po 65 različnih sekcij. Obiskovalcem zborovanja je zato v pomoč posebna aplikacija za pametne telefone, ki omogoča iskanje po referatih in sekcijah ter sestavljanje osebnih urnikov.

Upravni odbor AAG za vsako zborovanje izbere tri teme, ki jim nameni posebno pozornost. V New Orleansu so bile posebej izpostavljene: Črna geografija (Black geography), Naravne nesreče, geografija in geografska informacijska znanost (Hazards, Geography \& GIScience) ter Javna angažiranost in geografija (Public Engagement in Geography). Na izbiro sta odločilno vplivala lokacija zborovanja ter družbeno in politično dogajanje v ZDA v zadnjem obdobju.

Izbira prve teme ne preseneča, saj Afroameričani predstavljajo več kot $60 \%$ prebivalcev New Orleansa, zvezna država Misisipi pa ima med vsemi zveznimi državami največji delež Afroameričanov (nekaj nad 30 \%). »Črna geografija« je v ospredje postavila položaj Afroameričanov v ameriški družbi ter njihovo vlogo in položaj v ameriški geografiji. Med drugimi je izpostavila vlogo afroameriške skupnosti pri ustvarjanju prostorskih praks in geografskega znanja.

Tudi druga tema je tesno povezana z lokacijo zborovanja. Orkan Katrina, ki je prizadel New Orleans leta 2005, sodi med največje naravne nesreče, ki so prizadela ZDA v novejšem obdobju. Mesto si še vedno ni opomoglo po razdejanju, ki ga je povzročil orkan. Tema Naravne nesreče, geografija in geografska informacijska znanost je iz različnih perspektiv osvetlila problematiko naravnih nesreč. Predvsem je poskušala ugotoviti, kako lahko geografske in geoinformacijske raziskave preteklih dogodkov pripomorejo k boljši pripravljenosti na prihodnje dogodke. 
Obe temi je v plenarnem predavanju z naslovom When the Big Easy Isn 't So Easy: Learning from New Orleans' Geographies of Struggle odlično povezal predsednik AAG-ja Darek H. Alderman (predavanje je dostopno na spletu: https://www.youtube. com/watch?v=QDfTBsiS_DY).

Tema Javna angažiranost in geografija je odprla širšo razpravo o vlogi geografinj in geografov v družbi oziroma o družbeni angažiranosti geografije. AAG si že več let prizadeva, da bi geografija presegla ozke akademske okvire ter stopila v interakcijo z drugimi akademskimi disciplinami ter širšo javnostjo. Pri tem je pomembno, da znamo geografi jasno artikulirati, kaj in kako lahko ponudimo drugim disciplinam in širši javnosti. Udeleženci zborovanja so na različnih predavanjih, delavnicah in okroglih mizah dobili številne praktične napotke o aktivnem sodelovanju ter komuniciranju z javnostjo, hkrati so bili seznanjeni s ključnimi izzivi, problemi in nevarnostmi, ki spremljajo takšen angažma.

Poleg omenjenih tem je bila posebna pozornost namenjena tudi mladim geografom (študentom geografije in geografom na začetku karierne poti). Slednji predstavljajo več kot tretjino vseh udeležencev zborovanja ter znaten del članstva AAG-ja. V okviru AAG-ja že več let deluje zaposlitveni in karierni center, ki je v New Orleansu organiziral več posebnih delavnic, okroglih miz, panelov in predavanj na temo študija, raziskovanja in načrtovanja kariere. Na delavnicah so udeleženci dobili kopico praktičnih nasvetov o pisanju prošenj za zaposlitev, prijavljanju raziskovalnih projektov, mreženju, načrtovanju terenskega dela, objavljanju raziskav in podobnih opravilih, s katerimi se srečujejo mladi geografi. Razprave na okroglih mizah in panelih pa so v ospredje postavljale položaj geografov na trgu dela ter najpomembnejše trende na področju zaposlovanja geografov.

V okviru zborovanja je bila organizirana tudi razstava, na kateri so bila predstavljena najnovejša orodja na področju poučevanja, terenskega raziskovanja, računalniškega modeliranja, zbiranja in analiziranja podatkov ter grafične vizualizacije prostorskih podatkov. Na razstavi je sodelovalo 70 razstavljavcev. Med drugimi so bili prisotni vsi pomembnejši knjižni založniki, nekateri ponudniki programske in strojne opreme (med drugimi ESRI, Clark Labs, Pix4D), ponudniki statističnih in geoprostorskih podatkov (med drugimi US Geological Survey, US Census Bureau, China Data Center, NASA), različni inštituti in univerze ter informacijska podjetja (med večjimi razstavljavci je bilo podjetje Google).

Organizatorji zborovanja so pripravili tudi več ekskurzij, na katerih so udeleženci spoznavali New Orleans in njegovo geografijo. V ospredju ekskurzij so bile tri teme: »črna geografija«, multikulturni značaj mesta ter življenje v mestu po orkanu Katrina.

Zborovanja AAG je dogodek, ki se ga je vredno udeležiti. Čeprav je v prvi vrsti namenjen raziskovalcem, ponuja številne zanimive vsebine tudi učiteljem geografije (v New Orleansu je bilo področju didaktike namenjenih 16 sekcij in delavnic) in geografom, ki delujejo v različnih državnih institucijah in zasebnih podjetjih. Udeležba na zborovanju je še posebej priporočljiva za študente magistrskega in doktorskega študija geografije in sorodnih ved. Zborovanje AAG je namreč odličen poligon za spoznavanje novih/drugačnih pogledov na geografijo, študij geografije in geografsko raziskovanje.

Naslednje zborovanje AAG bo potekalo od 3. do 7. aprila 2019 v Washingtonu. Tisti, ki načrtujete bolj dolgoročno, pa si lahko zabeležite, da bo zborovanje leta 2020 gostil 
Denver, 2021 Seattle, 2022 New York, 2023 Detroit, leta 2024 pa bo zborovanje na Havajih. Zborovanje se navadno odvija v začetku aprila.

\section{Boštjan Rogelj}

Zborovanja Ameriškega združenja geografov v letu 2018 se je udeležilo več kot 8.500 udeležencev iz 84 držav (foto: B. Rogelj).

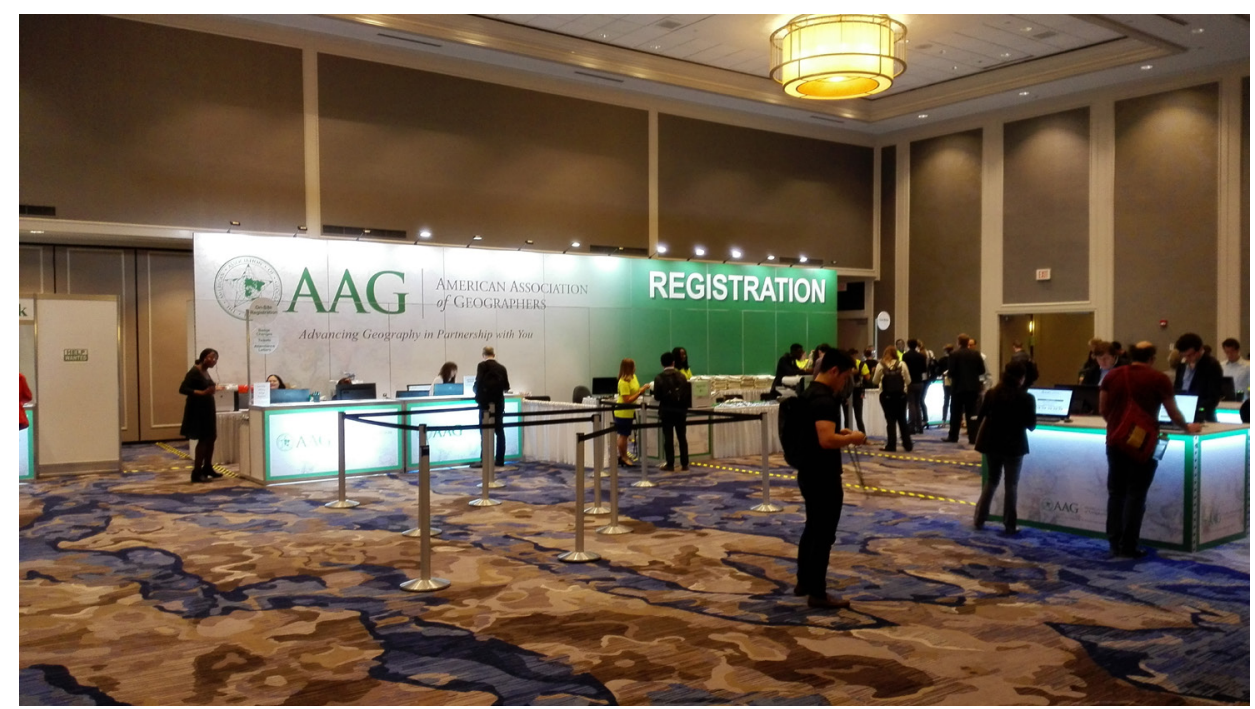

